Ethiopian Journal of Environmental Studies \& Management 10(3): 415 - 426, 2017.

ISSN:1998-0507

doi: https://dx.doi.org/10.4314/ejesm.v10i3.11

Submitted: January 23, 2017

Accepted: May 11, 2017

\title{
GENERATION RATE AND PHYSICAL COMPOSITION OF SOLID WASTE IN WOLAITA SODO TOWN, SOUTHERN ETHIOPIA
}

\author{
ENDRIAS GOA' ${ }^{1}$ AND SOLOMON SORSA SOTA ${ }^{2}$ \\ ${ }^{1}$ Humbo Woreda Environmental Protection and Forestry Office, Humbo, SNNPR, \\ Ethiopia \\ ${ }^{2}$ Hawassa University, College of Natural and Computational Sciences, Department of \\ Biology
}

\begin{abstract}
The ever increasing amount of solid waste generated which is exacerbated by lack of proper waste management system is of growing environmental and public health concern worldwide and in major towns and cities of Ethiopia. The aim of this study was to assess the current solid waste generation rate and compositions in Wolaita Sodo town, Southern Ethiopia. A cross-sectional survey and quantitative methods was used, and a multi-stage sampling method was employed including stratified random sampling, systematic random sampling, and purposive sampling. For house hold survey, sample size was determined using a population proportion formula. Structured and semi-structured questionnaire were used for interview, and direct waste analysis at source was used for waste characterization. A total of 378 household heads and 30 key informants were interviewed. The study showed that solid waste generation rate of Sodo town is $0.47 \mathrm{Kg} / \mathrm{cap} /$ day and this is greater than most major towns of Ethiopia. The major sources of municipal solid waste were residential, commercial and institutional sectors. The composition by weight of the households were food (59.5\%); ash and dust (25.08\%); yard waste (11.6\% ); plastics and rubber (2.04\%); paper and cardboard (1.12\%); and textile, wood, glass and metals accounted only $0.1 \%, 0.16 \%, 0.2 \%$ and $0.2 \%$ wastes, respectively. More than $97.6 \%$ of solid wastes generated from households and $93.7 \%$ of municipal solid waste were biodegradable wastes. The study revealed that the town generates about 18,858,464 $\mathrm{Kg}$ of solid waste by wet weight per year. The town municipality must develop an appropriate solid waste management plan and implement to properly manage this huge amount of solid waste.
\end{abstract}

Key Words: Wolaita Sodo, Solid waste, generation, composition

\footnotetext{
*Corresponding Author: Solomon Sorsa

Email: sorsasota@yahoo.com
} 


\section{Introduction}

Collecting and managing solid waste is an important challenge for countries across the world (Zerbock, 2003). Ogawa (2000) indicated that many cities and towns in developing countries are not able to manage solid wastes due to institutional, regulatory, financial, technical and public participation shortcomings.

Municipal solid waste management (MSWM) is one of the basic services that are currently receiving wide attention in many towns of Ethiopia. This is mainly because SWs that are generated in most towns of Ethiopia are not appropriately handled and managed (Dereje, 2001; Solomon, 2011; Endalu and Habtom, 2014; Afework, 2015 Mengie et al., 2015; Mohammed, 2015). However, it is possible to minimize and solve these problems through strictly planning and implementing different MSWM components and options.

The first and the most prerequisite step for provision of efficient MSWM is identification of major sources, and determination of generation rate and composition of MSW. This is because these elements are considered as a baseline for the rest of MSWM components. Thus, reliable and accurate data about these elements is very decisive. Therefore, the major objective of this study was to assess the household and MSW generation rate and physical composition in Sodo town.

\section{Materials and Methods \\ Study Area and Population}

Wolaita Soddo town, the administrative capital of the Wolaita zone, is located $390 \mathrm{Km}$ South and 167 $\mathrm{Km}$ of South West of Addis Ababa and
Hawassa, respectively. The town is located $6{ }^{\circ} 49$ " $\mathrm{N}$ latitude and $37^{\circ} 45^{\prime}, \mathrm{E}$ longitude. Currently, the total area of the town is about 3,200 hectares and is divided in to three sub town ("Kifleketema"), eleven "kebeles" (administrative units) and ninety nine villages ("mender"). Based on the 2010 Census, the town has a total population of 110,660 (male 58,407 and female 52,252) with the projected annual growth rate of the $4.8 \%$ (CSA, 2014).

Study Design, Sampling Procedure and Data Collection Tools

Cross-sectional survey design and quantitative methods was used in the study. The quantitative study method was used to collect data on demographic characteristic of the study participants; quantity and composition of SW generated, and factors contributing to increase in waste generation.

The study employed a multistage sampling method including stratified random sampling, systematic random sampling, and purposive sampling to identify or select the study sites and participants (households, Key Informants (KIs), SW sampling institutions and commercial establishments). From the three sub towns ("Merkato", "Mehal ketema" and "Arada"), a total of five kebeles were randomly selected i.e. two from Merkato (namely, "Merkato Gebeya" and "Fana"); two from Mehal ketema (i.e."Damota" and "Wadu") and one from Arada (i.e. Kidane mihret) that represent each cluster. The study participants HHs were randomly picked from sampling frame using systematic random sampling method. In this study HHs who lived in the town for one year or longer were considered. 
For the survey, sample sizes of HHs who participate in the study were determined using the single population proportion formula developed by Cochran (Cochran, 1977) with the desired degree of precision for general population. Therefore, sample size calculation gave a total of $378 \mathrm{HH}$ respondents.

A total of 30 KIs were purposely selected to participate in the study based on their wide exposure to SWM issues, the position they held in the community, their proximity to appreciate the problems of SWM. These included four road SW sweepers; three waste management experts from the town municipality; four private waste collector association members; five Kebele administrators; two town administration officers; three Wolaita University teachers; two Technical and Vocational Education Training (TVET) college teachers; three public health officers and four health extension workers.

To collect data from $\mathrm{HHs}$, a semistructured questionnaire with closed and open - ended interview questions were used and the interview was carried out by researchers in the house of the HHs. To collect data from KIs, a structured individual questionnaire was used, selfadministered to the $30 \mathrm{KIs}$ and collected back by the researcher.

\section{Solid Waste Samples Collection}

For SW sample collection, the same five kebeles and house of HHs selected for the survey were also used. Waste sample collection was focused on three types of SWs generated in the town, i.e., $\mathrm{HH}$, institutional, and commercial. A total of seven institutions and twenty commercial establishments were randomly selected. Furthermore, municipal waste samples were collected from the town waste dump site.

\section{Quality Assurance}

All the original questionnaires were prepared in English language and were translated into Amharic. To check the accuracy of the translation, a back translation was made. Pre-test of questionnaires was conducted to allow the researcher rehearse before the main study in order to check the clarity of the questions, to eliminate difficulties, and to estimate the length of time a respondent take to complete. Therefore, any problems in the content of the questionnaires were resolved during the pre-test.

\section{Data Analysis}

Statistical analysis of data was carried out using SPSS version 20.0 statistical package program. Data were recorded, organized and summarized in simple descriptive statistics methods and mean, percentage, frequencies and range were used to describe the findings.

\section{Ethical Considerations}

For the survey, ethical clearance was obtained from the Ethical clearance committee of Hawassa University. Before entering the study area, local authorities and community leaders were briefed about the objective of the study. Respondents participated in the study was voluntary and each respondent was asked to give verbal consent to participate and each $\mathrm{HH}$ was assured that the information provided will be kept confidential.

\section{Results and Discussion}

Socio-Demographic Characteristics of Study Participants

A total of $378 \mathrm{HHs}$ were participated in the study and among them $211(55.8 \%$ ) 
were males and 167(44.2\%) were females. Majority of the respondents $(78.0 \%)$ were $15-64$ years old and $22.0 \%$ of them were above age 65 years. Almost half $(51.3 \%)$ of $\mathrm{HH}$ completed secondary school, $32.0 \%$ completed primary school and only $8.2 \%$ and $6.9 \%$ were college/diploma and first degree and above holders, respectively. Majorities $(93.4 \%)$ of respondents were married and the remaining $3.4 \%$ and $3.2 \%$ were divorced and widowed, respectively (Table 1)

Considerable proportion $(31.5 \%)$ of HHs reported being merchants and the other occupations include private employee (24.6\%), daily laborers (14.6\%), civil servants $(11.9 \%)$ and others $(5.2 \%)$. However, about $12.0 \%$ of the respondents were unemployed at the time of the survey (Table 1).

Table 1: The Socio-demographic characteristics of household and Key Informants participated in the study

\begin{tabular}{|c|c|c|c|}
\hline \multirow{2}{*}{\multicolumn{2}{|c|}{ Socio-demographic characteristics }} & \multirow{2}{*}{\multicolumn{2}{|c|}{ Respondents }} \\
\hline & & & \\
\hline \multirow[t]{2}{*}{ Sex } & Female & $167(44.2) *$ & $16(53.3)$ \\
\hline & Male & $211(55.8)$ & $14(46.7)$ \\
\hline \multirow[t]{2}{*}{ Age } & & $295(78.0)$ & $27(90.0)$ \\
\hline & $\geq 65$ & $83(22.0)$ & $3(10.0)$ \\
\hline \multirow{5}{*}{$\begin{array}{l}\text { Educational } \\
\text { level }\end{array}$} & Unable to write and read & $6(1.6)$ & - \\
\hline & Primary school (1-8) & $121(32.0)$ & $2(6.7)$ \\
\hline & Secondary school (9-12) & $194(51.3)$ & $1(3.3)$ \\
\hline & College Diploma & $26(6.9)$ & $5(16.7)$ \\
\hline & First degree and above & $31(8.2)$ & $22(73.3)$ \\
\hline \multirow[t]{3}{*}{ Income } & Low income $\left(\leq 3000 \mathrm{ETB}^{*}\right)$ & $197(52.2)$ & - \\
\hline & Middle income (3001-6000 ETB) & $161(42.6)$ & - \\
\hline & High income (>6001 ETB) & $20(5.2)$ & - \\
\hline \multirow[t]{3}{*}{ Family size } & $1-3$ & $13(3.4)$ & - \\
\hline & $4-8$ & 22459.3 & - \\
\hline & $>8$ & $141(37.3)$ & - \\
\hline \multirow[t]{4}{*}{ Marital status } & Single & - & - \\
\hline & Married & $353(93.4)$ & - \\
\hline & Divorced & $13(3.4)$ & - \\
\hline & Widow/widower & $12(3.2)$ & - \\
\hline \multirow[t]{6}{*}{ Occupation } & Civil servant & $45(11.9)$ & - \\
\hline & Private employed & $93(24.6)$ & - \\
\hline & Traders/merchants & $119(31.5)$ & - \\
\hline & Daily laborers & $55(14.6)$ & - \\
\hline & Unemployed & $46(12.2)$ & - \\
\hline & Others & $20(5.2)$ & - \\
\hline
\end{tabular}

$*$ Values in parenthesis are percentage of $\mathrm{n} ; * *$ ETB $=$ Ethiopian Birr 
Almost half $(52.2 \%)$ of the $\mathrm{HHs}$ reported having low income and the middle and high income class accounted about $43.0 \%$ and $5.0 \%$, respectively. The low income, middle income and high income HHs family size was 5.6, 5.0 and 4.6, respectively and the average for Sodo town was $\mathrm{HHs}$ was 5.1 persons. Approximately $59.0 \%$ of the respondents had in average six family size and about $37.3 \%$ participant had more than eight family members (Table 1 ).

A total of $30 \mathrm{KIs}$ were participated in the study and among them 16(53.3\%) were female and 14(46.7\%) males. Almost all KIs (90\%) fall within age range of 15-64 years and 10\% were above 65 years. The majority of KIs (73.3\%) were first degree and above holders. About $16.7 \%$ were college diploma holders, $6.7 \%$ and $3.3 \%$ completed primary and secondary schools, respectively. About a third $(33.3 \%)$ of KIs were municipality experts, $26.7 \%$ were health officers and $16.7 \%$ were environmental experts. The others $13.3 \%$ and $10 \%$ were private association waste collectors and road sweepers, respectively (Table 1).

\section{Solid Waste Generation Rate}

The daily SW generation rate of Sodo town for low-income, middle and highincome $\mathrm{HHs}$ was $28 \mathrm{~kg} / \mathrm{capita} / \mathrm{day}, 0.38$ $\mathrm{kg} / \mathrm{capita} /$ day and $0.76 \mathrm{~kg} / \mathrm{capita} /$ day, respectively (Table 2). This indicates that the waste generation rate of higher income $\mathrm{HHs}$ was about 2.7 times higher than lower income HHs. Consistence with the findings of Wells (1996) and Ngoc and Schnitzer (2009), SW generation in Sodo town has direct relationship with income level. This may be as result of some HHs earning more and have better life standard (i.e., high- income HHs), and consequently use more consumable materials than low income $\mathrm{HHs}$ do, and hence the former group had the tendency to generate a larger quantity of SW per day. Similar trends were observed in Arada Sub-City of Addis Ababa (Yitayal, 2005; Solomon, 2006) Adama town (Lema, 2007) and Makurdi inNigeria (Sha' Ato, et al., 2007).

Similarly, occupation of respondents showed relationship to waste generation since most of the respondents (about $70.7 \%$ ) were merchants, employee in non-governmental and private sectors. Therefore; they might have earned more, hence have higher demands for goods to purchase and generate more wastes. Moreover, the marital status of HHs and their family size also showed a direct relationship with SW generation. The present study showed that the majority of study participant $\mathrm{HHs}$ were married (93.4\%) and the average family size of HHs was about 5.1, which is higher than that of overall family size of urban population of Ethiopia (i.e. 4.6) (CSA, 2001). For instance, married families usually have larger family size, and therefore generate more SWs. The HHs waste generation rate was found to be positively related with family size which means families with more individuals generate a larger quantity of SW per day. Similar trends were observed in Arada Sub-City Addis Ababa (Yitayal, 2005; Solomon, 2006), Adama town (Lema, 2007) and Makurdi-Nigeria (Sha'Ato et al., 2007).

The average SW generated in Sodo town is estimated to be 0.47 $\mathrm{kg} /$ capita/day; $14.2 \mathrm{Kg} / \mathrm{capita} / \mathrm{month}$ and $170.4 \mathrm{Kg} / \mathrm{capita} /$ year. This generation rate is higher when compared with study findings of comparable major Ethiopian 
towns, such as the $0.229 \mathrm{~kg}$ of Gambella town (Afework, 2015); $0.235 \mathrm{Kg}$ of Debre Markos (Mengie, Venkateswarlu and GopalaKrishna, 2015); $0.41 \mathrm{~kg}$ of Hossana (Endalu and Habtom, 2014); $0.157 \mathrm{~kg}$ of Jimma (Dagnew et al., 2012); $0.231 \mathrm{~kg}$ of Dessie (Solomon, 2006); 0.21 $\mathrm{kg}$ of Gondar (Mohammed, 2015); 0.267 $\mathrm{Kg}$ of Adama (Dereje, 2001); $0.277 \mathrm{Kg}$ of Mekelle (Gebretsadkan, 2002). But it is lower than the $0.55 \mathrm{~kg}$ of Debre Brihan town (Tyagi et al., 2014).

When compared with available data from some Ethiopian cities, per-capita SW generation of Sodo town is also higher than the $0.25 \mathrm{Kg}$ of Addis Ababa (Nigatu et al., 2011); $0.22 \mathrm{Kg}$ of
Bahirdar (Gebrie, 2009); $0.231 \mathrm{Kg}$ of Hawassa (Yeballeork, 2014) and 0.233 $\mathrm{Kg}$ for East African cities developed by WHO (Birke, 1999; Gebrie, 2009).

The annual SW generation (by weight) for the whole population of the town is estimated to be $18,856,464 \mathrm{Kg}$ or 20,789.9 tons (Table 2). This is higher than the $11,660,392 \mathrm{Kg}$ of Adama town (Lema, 2007); 11 million $\mathrm{Kg}$ of Hossana (Endalu and Habtom, 2014); 5,433,025 $\mathrm{Kg}$ of Gambella town (Afework, 2015); 4,197,600 $\mathrm{Kg}$ of Gondar (Mohammed, 2015); 8,276,375 Kg of Jimma (Melaku, 2008); and 4, 3353,600 $\mathrm{Kg}$ of Mekele (Dagnew et al., 2012).

Table 2: Solid waste generation rate of HHs in Sodo town $(n=378)$

\begin{tabular}{lllll}
\hline $\begin{array}{l}\text { Variables } \\
\text { (SW generation rate) }\end{array}$ & $\begin{array}{l}\text { Low income } \\
(\mathrm{n}=197)\end{array}$ & $\begin{array}{l}\text { Middle income } \\
(\mathrm{n}=161)\end{array}$ & $\begin{array}{l}\text { High income } \\
(\mathrm{n}=20)\end{array}$ & Average \\
\hline Average family size & 5.6 & 5.0 & 4.6 & 5.1 \\
Average Kg/HH/week & 10.89 & 13.36 & 24.63 & 16.26 \\
& $(5.50-16.53)$ & $(9.5-32.5)$ & $(15.0-40.50)$ & \\
Average Kg/HH/day & 1.56 & 1.91 & 3.52 & 2.33 \\
Average Kg/capita/day* & 0.28 & 0.38 & 0.76 & 0.47 \\
Kg/capita/month & 8.4 & 11.4 & 22.8 & 14.2 \\
Average & 100.8 & 136.8 & 273.6 & 170.4 \\
Kg/capita/year** & & & &
\end{tabular}

* SW generation $(\mathrm{Kg}) /$ capita/day $=\mathrm{Kg} / \mathrm{HH} /$ day divided by average family size;

**Total population of Wolaita Sodo town was 110,660 (CSA, 2014)

Almost all respondent KIs (Table 3) indicated that rapid population growth, increasing commercial activities, rapid urbanization, poor awareness of residents about environmental sanitation and socio economic status of HHs were the major causes of rapid increase in generation of
MSW. About $26.6 \%, 23.3 \%$ and $30 \%$ of respondents (Table 3), respectively, also indicated that construction activity, poor town planning and illiteracy, cultural and religious inclinations were also the driving force for increased MSW generation. 
Table 3: Factors that contribute to an increase in MSW generation as reported by KIs $(\mathrm{n}=30)$

\begin{tabular}{lll}
\hline Causes & Yes & No \\
\hline Rapid population growth & $30(100 \%)$ & - \\
Rapid urbanization & $30(100 \%)$ & - \\
Increase in Commercial activities & $30(100 \%)$ & - \\
Increased construction activities & $8(26.6 \%)$ & $22(63.4 \%)$ \\
Poor town planning & $7(23.3 \%)$ & $23(66.7 \%)$ \\
Improved socio economic status of HHs. & $30(100 \%)$ & - \\
Poor awareness of residents about environmental sanitation & $30(100 \%)$ & - \\
Illiteracy, cultural and religious inclination & $9(30 \%)$ & $21(70 \%)$ \\
\hline
\end{tabular}

According to "Yedamot Tsedal" (2004), waste generation rate of Sodo town has increased in the last couple of years. Constant with the current study result (Table 3), the driving forces behind that increase in Sodo town and elsewhere in other developing countries are rapid increase of population size, increased commercial activities, changing consumption patterns, economic development, and changing income (Ngoc and Schnitzer, 2009). Rapid population boom is due to rural-urban migration. The reasons for rapid urbanization and commercial activities seems to be due to good and attractive urban development policy encouraged by the government and the town being a gate way and center of business for all "Woredas" within the zone, special woredas and other zones.

\section{Physical Composition of Solid Wastes}

Eighty percent of the KIs ranked SW sources in descending order as: residential, street, hotels, commercial and institutional wastes. This result is almost similar to that (except industrial sources) reported by Tadesse (2004) in Addis Ababa. The major composition of the $\mathrm{HH}$ SW were food $(59.5 \%)$; ash and dust (25.08\%); yard waste (11.6\%); plastics and rubber $(2.04 \%)$; paper and cardboard
(1.12\%); and textile, wood, glass and metals accounted only $0.1 \%, 0.16 \%$, $0.2 \%$ and $0.2 \%$ wastes, respectively (Table 4). This result shows that municipal waste is an aggregate of all substances ready for disposal or disposed in the study area. The composition of the solid organic waste was almost homogenous in nature across the study HHs.

In present study, the largest proportion $(59.5 \%)$ of total $\mathrm{HH}$ SW was food (Table 4). Moreover, the proportion of food waste $(81.9 \%)$ at damp site of the Sodo town (Table 5) was much higher than that reported from Adama (37.8\%) (Solomon, 2006) and Debre Berhan (33.0\%) (Tyagi et al., 2014).

Tchobanoglous et al. (1993) stated that the larger portion of SWs of developing countries is food waste. Likewise, Cointreau and Coad (2000) confirmed that wastes from urban areas in developing countries have a much higher percentage of food waste in their over all waste mix. For example, 36\% in Makurdi-Nigeria, (Sha'Ato et.al., 2007), $40.7 \%$ in Guadalajara, Mexico (Perez et al., 2008). These proportions were lower than that reported in the present study.

Waste generated from offices, academic institutions (schools, university 
and colleges) and health care facilities were categorized as institutional wastes. The physical composition analysis of SW revealed that $41.0 \%$ of institutional wastes were paper and paper products followed by food wastes (32.0\%), plastics (11\%), and construction wastes $(5.0 \%)$. The ash and dusts; yard waste; wood; e-waste; glass; textiles; metals; accounted a small fractions, i.e., $2.5 \%$, $2 \%, 1.5 \%, 1.0 \%, 1.0 \%, 1.0 \%, 0.5 \%$ and $1.5 \%$, respectively (Table 4 ).

Results (Table 4) of the present study indicated that fractions of paper and related wastes were higher in institutional SWs followed by commercial wastes. Plastic and rubber wastes were also higher in commercial wastes $(12.4 \%)$ followed by institutional SWs (11.0\%). The amount of above mentioned wastes were relatively lower in municipal disposal site. The possible reasons for this might be the largest fractions of these wastes were burned at sources of generation either at $\mathrm{HH}$, institutes or municipal level. The proportion of plastic and rubber reported in present study (5.0\% by weight) is higher than the $4.8 \%$ of Hosaina n (Endalu and Habtom, 2014) and the $2.9 \%$ of Adama (Lema , 2007).

The average biodegradable SW share of $\mathrm{HH}$, commercial and institutional was found to be $97.6 \%, 75.2 \%$ and $79.0 \%$, respectively. When the average proportion of biodegradable SW share of the three sectors is considered together, the first three highest compositions were food $(42.2 \%)$, paper and cardboard (22.7\%); and ash and dust (10.8\%) wastes (Table 4).

Table 4: Physical composition of SW of residential, commercial and institution sectors by proportion of wet weight.

\begin{tabular}{|c|c|c|c|c|c|}
\hline \multirow[t]{2}{*}{ SW category } & \multirow[t]{2}{*}{ SW composition } & Residential ** & Commercial & Institutional & \multirow{2}{*}{$\begin{array}{l}\text { Average } \\
\% \text { share }\end{array}$} \\
\hline & & $\%$ by $\mathrm{Wt}^{*}(\mathrm{Kg})$ & $\%$ by $\mathrm{Wt} *(\mathrm{Kg})$ & $\%$ by $\mathrm{Wt}^{*}(\mathrm{Kg})$ & \\
\hline \multirow[t]{7}{*}{ Bio-degradable } & Food waste & 59.5 & 35.0 & 32.0 & 42.2 \\
\hline & Ash and dust & 25.1 & 4.8 & 2.5 & 10.8 \\
\hline & Yard waste & 11.6 & 0.5 & 2.0 & 4.7 \\
\hline & Paper and cardboard & 1.1 & 26.1 & 41.0 & 22.7 \\
\hline & Wood & 0.2 & 5.2 & 1.0 & 2.1 \\
\hline & $\begin{array}{l}\text { Textile (Worn out } \\
\text { cloth) }\end{array}$ & 0.1 & 3.6 & 0.5 & 1.4 \\
\hline & Total & 97.6 & 75.2 & 79.0 & 83.9 \\
\hline Non- & Metals & 0.2 & 6.4 & 1.0 & 2.5 \\
\hline \multirow[t]{4}{*}{ biodegradable } & Plastic and rubber & 2.0 & 12.4 & 11.0 & 8.5 \\
\hline & Glass & 0.1 & 2.2 & 1.5 & 1.3 \\
\hline & E-wastes & 0.01 & 1.6 & 1.0 & 0.9 \\
\hline & Total & 2.4 & 22.6 & 14.5 & 13.2 \\
\hline Others (mixed) & & 0.03 & 2.2 & 6.5 & 2.9 \\
\hline
\end{tabular}

* Wt $=$ weight; ** Residential refers to $\mathrm{HH}$ waste

The results (Table 5) of a study on dampe site of Sodo town municipality revealed that the highest proportion $(81.9 \%)$ was food wastes and plant materials (such as wood, leaves, grass, etc) accounted about $10.0 \%$ of the waste. Other type wastes identified included: plastics and rubber $(2.3 \%)$, paper and cardboards (1.0\%), 
textile $(0.76 \%)$, glass $(0.62 \%)$, and metals $(0.4 \%)$. Furthermore, the immerging waste like electrical and electronics (e-wastes) account only small fractions $(0.6 \%)$ that included CD/VCDs; broken cell phones; parts of computers, television, radio, etc. The total proportion of biodegradable waste at disposal site of Sodo town was $93.7 \%$ (Table 5).

The present study also revealed that the combined share of total biodegradable SWs for the three sectors and that identified from damp site of Sodo town were $83.9 \%$ (Table 4) and $93.7 \%$ (Table $5)$, respectively. Such a high proportion has been reported by studies conducted in many different cities of most of the developing and developed countries and in many different cities and town of Ethiopia. For example organic waste constitute of $80.0 \%$ in Debre Berhan (Tyagi et al., 2014), 2014), $59.17 \%$ in Addis Ababa (Arada Sub-City) (Yitayal, 2005); 74\% in Indonesia (Walhi, 2001) and $52-65 \%$ in Nigeria (Imam et al. 2008).

Table 5: Average physical composition of municipal solid waste sampled from disposal site.

\begin{tabular}{lll}
\hline SW category & SW composition & Percent by weight \\
\hline Bio-degradable & Food waste res & 81.9 \\
& Wood, leaves, grasses & 10.0 \\
& Paper and cardboard & 1.0 \\
& Textiles (Worn out cloth) & 0.8 \\
Non- & Total & 93.7 \\
biodegradable & Plastics and rubber & 2.3 \\
& Metals & 0.4 \\
& Glass & 0.6 \\
Mixed & Electronic wastes & 0.6 \\
& $\quad$ Total & 3.9 \\
\hline
\end{tabular}

Solid waste generated in Sodo town has high content of biodegradable waste (ash, food waste, yard waste, etc.) that can be composite (about $84.0 \%$ of $\mathrm{HH}$ waste) and recyclables material (plastics, glass, metals, etc.) about $13.0 \%$. These all account for about $97.0 \%$ of the total waste generated in the town and if all could be recycled and reused, the municipality would remain with almost $3.0 \%$ waste to be disposed. A similar trend was observed in Jimma town (Melaku, 2008) and Gambella towns (Afework, 2015). Moreover, investment in recycling and composting would create job and engage a good number of the unemployed, greatly reducing the quantity of SW to be disposed. Furthermore, recycling will recover raw materials which would otherwise be wasted.

\section{Conclusion}

Findings of this study indicated that the biodegradable and recyclables material in the SW generated in the town waste account for about $97.0 \%$ of the total. If at source sorting, composting of 
the organic waste and recycling should be encouraged and formalized, cost of SWM in the town would be greatly reduced and job will be created. This calls for the town authorities to develop plans, policies, rules and regulations to that effect.

Furthermore, the HHs average SW generation per-capita/day in Sodo town is $0.47 \mathrm{Kg}$ and the town generates more than $18,856,464 \mathrm{Kg}$ of SW (by weight) per year. This huge amount of SW generated in the town requires a good management to protect and bring about a healthy and sustainable environment. Therefore, the town municipality must develop an appropriate SWM plan and promptly implement it. Developing such management plan requires understanding the existing SWM practice in the town. Thus, a detailed further study must be conducted on existing knowledge, attitude and practice of the community in WM; existing WM practices and problems in the town, stalk holder's and public participation in WM, etc.

\section{Acknowledgements}

We would like to thank Sodo town municipality and administration for facilitating and overall cooperation during the study. We also thank the households and Key Informants for their cooperation during data and sample collection.

\section{References}

Belay, A. (2015). Household generation rate and composition analyses in Adama town. M.Sc thesis, School of Natural Resource Management and Environmental Science, Haramaya University, Ethiopia.
Birke, Y. (1999). Solid waste management in Ethiopia. Paper presented on $25^{\text {th }}$ WEDC conference in the Integrated Development for Water Supply and Sanitation, Addis Ababa, Ethiopia.

Central Statistic Authority (CSA) (2014). The 1999 population projection of Sodo town, 2013/14 Statistical Abstract, Sodo, SNNPR, Ethiopia.

Central Statistics Authority (CSA). 2001. Report on the 1999/2000 household incomes, consumption and expenditure Survey (HICE). Statistical Bulletin 258, Addis Ababa, Ethiopia.

Cochran, W.G. (1977). Sampling Techniques. $3^{\text {rd }}$ ed. Wiley series in Productivity and applied mathematical statistics. New York, John Wiley and Sons, Inc. USA.

Cointreau-Levine, S. and Coad, A. (2000). Guidance pack - Private sector participation in municipal solid waste: Part I. Executive overview, SKAT- Swiss Centre for Development Cooperation in Technology and Management, Switzerland.

Dagnew Hagos, Alemu Mekonnen and Zenebe Gebreegziabher (2012). Households' willingness to pay for improved urban waste management in Mekelle city. Environment for Development, Discussion Paper Series EfD DP 12-06, Ethiopia.

Dereje Tadesse. (2001). Financial Urban Infrastructure and Services in Ethiopia: The Case of Solid Waste Management in Adama Town, Ethiopia.

Endalu Lemma and Habtom Tekilu. (2014). Characterization and disposal of municipal solid waste, 
case study, Hosanna town. American Journal of Environmental Engineering, 4: 162168.

Gebretsadkan GebreMichal (2002. Domestic solid waste management in Mekelle city. Tigray Region, Ethiopia.

Gebrie Kassa (2009). Management of domestic solid waste in Bahirdar town: Operational analysis and assessment of constraints that affect solid waste management, Addis Ababa, Ethiopia.

Imam, A., Mohammed, B., Wilson, D.C. and Cheeseman C.R. (2008). Solid waste management in Abuja, Nigeria. Waste Management, 28: 468 - 472.

Lema Asfaw (2007). Household solid waste generation rate and composition analysis in two selected kebeles of Adama town, MSc thesis, School of Graduate Studies, Addis Ababa University, Ethiopia.

Melaku Tegegn (2008). Household solid waste generation rate and physical composition analysis, in Jimma town, Ethiopia. MSc thesis, School of Graduate Studies, Addis Ababa University, Ethiopia.

Mengie Belayneh, Venkateswarlu, M. and GopalaKrishna, V.B. (2015). Solid waste generation and solid waste disposal site Management in urban areas: the case of Dessie town, Amhara National Regional State, Ethiopia. International Journal of Advanced Scientific and Technical Research, 3: 293 - 307

Mohammed Gedefaw (2015). Assessing the current status of solid waste management of Gondar town,
Ethiopia. International Journal of Scientific and Technology Research, 4: 28 - 36.

Ngoc, N. U. and Schnitzer, H. (2009). Sustainable Solutions for solid waste management in South East Asian Countries, Waste Management, 29: 1982-1995.

Nigatu Regassa, Sundaraa R.D. and Bizunesh Bogale (2011). Challenges and opportunities in municipal solid waste management: The case of Addis Ababa city, central Ethiopia. Journal of Human Ecology, 33: 179-190.

Ogawa, H. (2000). Sustainable SW management in developing countries. 7th ISWA International Conference and Exhibition, World Health Organization, Kuala Lumpur, Malaysia. Retrieved from http://www.gdrc.org/uem/waste/sw m-fogawal.htm

Perez, G.B., Colon, S.S., Garmendia, M.A., Villareal, A.D. and Elena, M.S.S. (2008). Solid waste characterization study in the Guadalajara Metropolitan Zone, Mexico. Waste Management Research, 19: 413-424.

Sha'Ato, R., Aboho, S.Y., Oketunde, F.O., Enegy, I.S., Unazi, G. and Agwa, S. (2007). Survey of solid waste generation and composition in a rapidly growing urban area in central Nigeria. Waste Management, 27: 352-358.

Sodo Town Administration. Annual report. 2014. Wolaita Zone, SNNPR, Ethiopia.

Solomon Asrat (2006). Solid Waste Management: A Case Study of Household Solid Waste 
Management in Arada Sub-City, Addis Ababa, Ethiopia.

Solomon Cheru (2011). Assessment of municipal solid waste management service in Dessie town. MSc thesis, School of Graduate Studies, Addis Ababa University, Ethiopia.

Tadesse Kuma (2004). Dry Waste Management in Addis Ababa City. A paper presented on teaching workshop on Accounting for urban environment, January 5th -16 th, Addis Ababa, Ethiopia.

Tchobanoglous, G., Thiesen, H. and Vigil, S. (1993). Integrated Solid Waste Management: Engineering Principles and Management Issues. McGraw-Hill, Inc., New York, USA.

Tyagi, V., Fantaw, S. and Sharma, H.R. (2014). Municipal solid waste management of Debre Berhan City of Ethiopia. Urban Management and climate change department, Ethiopian Civil Service University, Addis Ababa, Ethiopia Vol. 4, No.5.

Walhi, J. (2001). A long way to Zero Waste Management. Proceedings of the Waste-Not- Asia Conference, Taiwan, Global Alliance for Incinerator Alternatives.

Wells, D. (1996). Environmental Policy: Abnormal Perspective to the twenty-first century. Prentice-Hall, New Jersey, USA.

Yedamot Tsedal' (2004). Wolaita sodo city profile. The $6^{\text {th }}$ Ethiopian Cities Forum, Diredawa. November 2014. Wolaita sodo city Administration 2014, Wolaita sodo, Wolaita zone, Ethiopia.

Yeballework Bibisso (2014). Assessment of municipal solid waste management: The case of Hawassa town, Southern Nation, Nationalities and Peoples Regional State. MSc thesis, College of Social Sciences and Humanities, Haramaya University, Ethiopia.

Yitayal Beyene (2005). Domestic solid waste quantity and composition: Analysis in Arada Sub-City, Addis Ababa. MSc thesis, School of Graduate Studies, Addis Ababa University, Ethiopia.

Zerbock, O. (2003). Urban solid waste management: waste reduction in developing nations. Houghton, MI: School of Forest Resources and Environmental Science, Michigan Technological University 2003. Retrieved from http: $/ / w w w$. cee.mtu.edu/ sustainableengineering/resources/te chnical/wastereduction-andncineration.FINAL,pdÆ Web. 